Current Research Journal of Economic Theory 10(1): 1-10, 2018

DOI:10.19026/crjet.10.5921

ISSN: 2042-4841, e-ISSN: 2042-485X

(C) 2018 Maxwell Scientific Publication Corp.

\begin{tabular}{lll}
\hline Submitted: June 7, 2018 & Accepted: July 6, 2018 & Published: November 20, 2018
\end{tabular}

\title{
Research Article \\ Foreign Direct Investment-Economic Growth Nexus: The Role of Human Capital Development in the Common Market for Eastern and Southern Africa Region
}

\author{
${ }^{1}$ Peter Kitonyo and ${ }^{2}$ Musa Njiru Kathanje \\ ${ }^{1}$ School of Economics, University of Nairobi, \\ ${ }^{2}$ School of Business, Jomo Kenyatta University of Agriculture and Technology, Nairobi, Kenya
}

\begin{abstract}
This study uses country-level panel data to investigate the impact of foreign direct investment on the gross domestic product per capita in the Common Market for Eastern and Southern Africa region over the 20002015 period. The estimates are generated using the one-step generalized method of moments-difference estimator. The study found that foreign direct investment exerted a negative while human capital development has a positive impact on the gross domestic product per capita in the region. Additionally, the development of human capital has a positive effect on the ability of the region to absorb and benefit from the spillovers of foreign direct investment. The findings suggest that the countries of the region should target to attract foreign direct investment which complements economic growth and improve on the development of human capital in order to continue realizing positive economic growth from the said investment.
\end{abstract}

Keywords: COMESA, economic growth, foreign direct investment, generalized method of moments, human capital development

\section{INTRODUCTION}

FDI is defined as an investment made by an investor to acquire a lasting interest of management of $10 \%$ or more of voting stock and equity shares in a business enterprise with operations in an economy different from that of the investor (Mwilima, 2003; World Bank, 1996). Foreign direct investment is in forms of brick and mortar investment and Merger and Acquisition (M\&A), which involves the acquisition of existing interest as opposed to a new investment. FDI also take the form of international joint ventures related to mergers ${ }^{1}$. FDI is further classified into marketseeking, resource-seeking and efficiency-seeking types (Ajayi, 2007; Campos and Kinoshita, 2003).

FDI is associated with a positive contribution to the economic growth in recipient countries. FDI could close the gap between desired levels of investment and savings mobilized from domestic sources, increase tax revenues, improve skills of management, technology and workforce skills in recipient economies (Hayami, 2001; Todaro and Smith, 2003). Additionally, FDI may include the acquisition of modern technology, creation of employment opportunities, development of human capital, improved integration of foreign trade, complement domestic investment, generation of revenue, introduction of modern and efficient processes, impeccable skills of management and know- how in the local market, employee training, improved foreign production networks and improved access to large markets (Ajayi, 2005; Findlay, 1978; Jenkins and Thomas, 2002; Mwilima, 2003; World Bank, 2000).

Conversely, FDI may create inadequate employment opportunities and lead into limited capital formation (Adams, 2009), crowd-out or replace domestic investment, lead to balance of payments challenges and create the enclaves economy (Mwega and Ngugi, 2007; Ugochukwu et al., 2013). Foreign firms may fail to encourage entrepreneurship in the domestic economy; generate little revenues through taxes; repatriate profits to parent country instead of reinvesting the same in the local economy; develop limited forward and backward linkages with domestic firms; and can utilize capital-intensive techniques of production that are inappropriate in the domestic countries (Firebaugh, 1992).

Despite these advantages policy analysts and researchers have not accorded considerable attention to the relationship between FDI and economic growth in developing countries.

The inflow of FDI has been on the increase in Africa and sub-Saharan Africa in general and the COMESA region in particular. According to the data from the United Nations Conference on Trade and Development (2016) the net FDI stocks as a share of GDP averaged $29.0 \%$ over the $2000-2015$ period. They

Corresponding Author: Peter Kitonyo, School of Economics, University of Nairobi, P.O. Box 30197-00100, Nairobi, Kenya, Tel.: +254 20722778397

This work is licensed under a Creative Commons Attribution 4.0 International License (URL: http://creativecommons.org/licenses/by/4.0/). 
rose from $21.0 \%$ in 2000 to $36.4 \%$ in 2014 before falling to $27.9 \%$ in 2015 . The net FDI stocks were not homogeneously distributed within the COMESA region as much of the investment was attracted by the resource-rich economies. In fact, out of the total FDI net stocks received in the region over the 2000-2015 period, Egypt accounted for the highest net FDI stocks, followed by Sudan, Libya, Zambia, Uganda and Ethiopia (United Nations Conference on Trade and Development, 2016).

Africa has also experienced fast growth since 2000 and sub-Saharan Africa is the third fastest growing region (5.59\%/annum) after emerging markets and developing economies (5.98\%) and developing Asia (8.39\%/annum) (International Monetary Fund, 2016). The COMESA region experienced high economic growth rate since 2000 , realizing highest growth rates of $3.9 \%$ in 2007 and $8.3 \%$ in 2012 (International Monetary Fund, 2016). The region's GDP/capita growth rate rose from an average of $0.46 \%$ in 2000 to $2.79 \%$ in 2015 . Overall, the region experienced an average real GDP/capita growth rate of $1.9 \%$ between 2000 and 2015. This is slightly higher than GDP growth of $1.8 \%$ realized in the advanced economies during the same period. Finally, many member countries of the region are the fastest growing in Africa (International Monetary Fund, 2016) ${ }^{2}$.

However, the growth impact of the increased FDI in the region is not well known. This is because, to the best of our knowledge, there are no similar studies conducted in the region in the past and previous regional empirical studies carried out omit all the COMESA countries from their analysis. They include Jugrnath et al. (2016), Mutenyo (2008), Ndoricimpa (2009) and Seetanah and Khadaroo (2006), among others. Further, empirical evidence suggests that the growth impact of FDI is conflicting. The results shows that the impact is either positive, negative or even indeterminate. For instance, Jugrnath et al. (2016), Mutenyo (2008), Ndoricimpa (2009) and Seetanah and Khadaroo (2006) reveal that FDI exert a positive impact on the economic growth while Agbloyor et al. (2014), Bos et al. (1974), Prebisch (1968), Saltz (1992) and Singer (1950) found FDI to have a negative effect on growth. Alternatively, other authors, including Agbloyor et al. (2016), Carkovic and Levine (2002) and De Mello (1999) find that FDI has no impact on economic growth of recipient economies.

This study is aimed at establishing the growth effect of FDI in 19 developing countries of the COMESA region over the time period 2000-2015. It tests the hypothesis that increased inflows of FDI exert a positive impact on the GDP/capita of the COMESA region by applying a dynamic panel data analysis and employing the one-step Generalized Method of Moments (GMM) estimation technique suggested by Arellano and Bond (1991).

\section{LITERATURE REVIEW}

Theoretically, FDI can promote economic growth in a number of ways. Some analysts propose that the growth effects of FDI are expected to be two fold (De Mello, 1999; Kim and Seo, 2003). On the one hand, FDI can affect GDP/capita growth of an economy via accumulation of capital by introducing new products and exotic technology. This viewpoint is held by exogenous growth theorists. According to standard neoclassical growth models, countries with low domestic savings attract FDI to help in the process of accumulation of capital. Such inflow of capital allows COMESA region economies to grow faster than they could with their current financial resources. However, the model suggests that diminishing returns to physical capital occur and lead to growth effects of FDI being limited to the short run.

On the other hand, FDI can promote economic growth via augmentation of the knowledge stock in the host economy by knowledge transfer. This viewpoint is held by endogenous growth theorists. According to endogenous growth models, FDI can promote growth both in the long-run and short-run. Endogenous growth theory suggests that FDI facilitates the use of local raw materials, introduces modern management practices, brings-in new technologies, helps in financing current account deficits, increases the stock of human capital via on the job training and labor development and increases the investment in research and development. FDI, theoretically, can therefore play a key role in economic growth via increasing capital accumulation and spillovers or progress of technology (Herzer et al., 2008).

Many researchers have found direct positive effect of FDI on growth of GDP per capita of host economies. They include De Mello (1997) who found that FDI has a positive effect on the economic growth of developing countries of Latin America and Campos and Kinoshita (2003) who found that FDI had a positive and statistically significant impact on the GDP/capita growth of 25 transition countries of Central and Eastern Europe and former Soviet Union.

In turn Seetanah and Khadaroo (2006) examined the association between FDI and the performance of the economies of 39 African countries over the 1980-2000 period using a panel data technique. Results from the static random effects estimates showed that FDI impacted positively on the level of economic growth. The results also confirmed existence of positive link when using GMM panel estimates in a dynamic panel analysis. Mutenyo (2008) assessed the influence of FDI on the GDP/capita in 32 countries in sub Saharan Africa. The author used both a static panel regression with fixed effect and a dynamic panel using the GMM estimator and found that FDI has a positive impact on economic growth but less efficient as compared to the private domestic investment. 
Additionally, Jugrnath et al. (2016) examined the growth impact of FDI for a panel of 32 sub-Saharan African countries during the period 2008-2014. They used static panel regressions techniques and dynamic panel estimates to assess the causal link of FDI, trade openness, domestic investment, working population size and the effect of the 2009 European debt crisis on the GDP. They found a strong positive relationship between FDI and GDP.

Alternatively, other authors find that FDI have an indeterminate effect on the GDP/capita growth. They include Agbloyor et al. (2016) who investigated the relationship among FDI, institutions and economic growth in sub-Saharan Africa in various country conditions. They used a two-step GMM estimator with Weidmeijer corrected standard errors and orthogonal deviations to investigate the empirical relations. They found no evidence to support the hypothesis that FDI promote growth. They also did not find a significant relationship between institutions and economic growth. Others are Borensztein et al. (1998) who revealed that FDI inflows marginally affected growth for a sample of 69 developing economies and Carkovic and Levine (2002) applied a GMM panel data analysis on pooled data drawn from 72 countries in the period 1960-1995 and suggested that FDI does not have a positive impact on growth. De Mello (1999) and Katerina et al. (2004) also established that FDI had no impact on economic growth of recipient economies.

In contrast, other researchers observed FDI to have a negative direct effect on growth of the host nations. They include Prebisch (1968) and Singer (1950) who argued that the host economies of foreign direct investment do not obtain large benefits from this investment because most FDI benefits are shifted to the parent country of the multinational corporations. Other authors including Bos et al. (1974) advanced the view that FDI adversely affects the rate of growth due to price distortions of factors of production caused by protectionism, monopolization of the market and depletion of natural resources. However, Bos et al. (1974) added that FDI raises the level of investment and perhaps the productivity of investments as well as the consumption in the host country. Saltz (1992) also concluded that foreign direct investment has an adverse effect on growth.

Similarly, Agbloyor et al. (2014) examined the relation between private capital flows and economic growth in Africa during the period 1990-2007 using a panel Instrumental Variable Generalized Method of Moments (IV-GMM) estimator to control for endogeneity and heteroscedasticity. They found that FDI, foreign equity portfolio investment and private debt flows had a negative impact on economic growth.

It is clear that empirical evidence on the effects of FDI on economic growth provides conflicting results. One of the explanations to justify the controversy of the empirical evidence on the effects of FDI on GDP/capita growth is that, the effect of FDI on GDP/capita is dependent on the human capital development and other absorptive capacity measures including the technology gap, the development of the financial sector, infrastructure and quality of institutions, among others. Additionally, the host country requires to reach a minimum threshold of such absorptive capacity, before benefiting from the effects of foreign direct investment on growth.

Human capital development is an important channel for transferring and receiving benefits of FDI in the host countries. According to Blomström and Kokko (1998) labour force in terms of human capital and education allows for absorption and adaptation of foreign technology and generation of sustainable economic growth in the host countries. The benefits of FDI are transferred to human capital development via training, learning by doing and work experience accumulation. The human capital development provides the force required to implement the technology and know-how conveyed by the FDI. Better skilled and educated labour is likely to allow for efficient and effective reception of new technology and achievement of better economic performance.

Van den Berg (2001) advanced that the ability of an economy to create new knowledge and ideas and adapt old knowledge and ideas is determined by the quality of the labour force. The author added that high quality labour force is required to install projects especially at the stage of disbursing investment. The author also observed that the shortage of qualified people may lead to a slow and stuck installation of development projects. Low skilled and educated workers negatively impact on investment disbursement and adversely affect the ability of the host country to promote FDI. Further, Chen (1990) observed that host economies with high quality and higher amounts of human capital investment are able to gain more benefits from FDI.

Other researchers who hold a similar view include Borensztein et al. (1998), $\mathrm{Xu}$ (2000) and Balasubramanyam et al. (1996). For instance, Borensztein et al. (1998) investigated the effect of FDI on economic growth in 69 developing countries applying cross-sectional and cross-country regressions. The authors applied panel data for 20 years (1970-1979 and 1980-1989) and estimated the regressions utilizing cross-section regressions and the Seemingly Unrelated Regressions method (SUR). They found that FDI is a critical channel in technology transfer, but the effectiveness of the FDI is dependent on the human capital stock in the host economy. The authors observed that FDI had a positive contribution to economic growth only in countries where the stock of human capital is above a certain threshold with a highly qualified workforce. The host economies with low stock of human capital experienced negative direct effects of FDI on economic growth. Similar findings are also reported by $\mathrm{Xu}(2000)$ for 40 economies (20 
developed countries and 20 less developed countries) between 1966 and 1994. The author examined the effect of the presence of the affiliates of the multinational corporations on the productivity growth of the host economy. The authors applied the panel data Two Stages Least Square (2SLS) technique and established that developing countries gain positively from transfer of technology offered by US multinational corporations but not in less developing countries. The author concluded that less developing countries do not reach the required minimum threshold of human capital.

In turn, Balasubramanyam et al. (1996) found that FDI had a positive and significant impact on economic growth subject to achievement of a certain threshold of human capital stock in the recipient country. The authors also observed that FDI complements local investment. Utilizing a panel data for 84 countries from 1970 to 1999, Li and Liu (2005) established that the interaction of foreign direct investment with the stock of human capital exhibited a statistically significant positive impact on economic growth. The foregoing literature review suggests that, in order to obtain the benefits of FDI, the recipient country require minimum threshold of high quality stock of human capital.

As such, while the theoretical literature points out that FDI has positive growth impacts, the empirical evidence gives conflicting outcomes. Also, regional empirical studies that examine the impact of FDI on the economic growth in the COMESA region are missing in the literature.

\section{METHODOLOGY}

Data: This study utilizes annual panel data covering the period between 2000 and 2015 for Burundi, Comoros, Djibouti, Democratic Republic of Congo, Egypt, Eritrea, Ethiopia, Kenya, Libya, Madagascar, Malawi, Mauritius, Rwanda, Seychelles, Sudan, Swaziland, Uganda, Zambia and Zimbabwe. The data is drawn from different sources and compiled to suit the analysis. These are countries found in the COMESA region.

The data on the GDP/capita, inflation and public debt was obtained from the International Monetary Fund, World Economic Outlook reports (various years), while the data on domestic investment (represented by gross capital formation) was obtained from the World Bank, World Development Indicators (various years). Finally, the data on the human capital development was obtained from the United Nations Development Programme (UNDP), Human Development Index (HDI) report (various years).

Theoretical framework: In order to examine the impact of FDI on economic growth of the Common Market for Eastern and Southern African countries, the theoretical growth model is constructed following Kitonyo (2018) to obtain Eq. (1):

$$
Y_{i, t}=A_{i, t} L_{i, t}^{\alpha} K_{D}^{\beta}{ }_{i, t} K_{F}{ }_{i, t}
$$

where,

$Y \quad$ : The flow of output

$A$ : The total factor productivity

$K_{D}:$ The domestic capital

$K_{F}:$ FDI

$L \quad$ : The labor force

$\alpha \quad$ : The output changes to labor force changes

$\beta$ : The output changes to domestic capital or local investment changes

$\theta \quad$ : The changes in output to changes in FDI

$\alpha, \beta$ and $\theta$ are assumed to be $<1$, implying diminishing returns to each factor input. The subscripts $i$ and $t$ represent the cross-sectional member countries of the COMESA region and time period, respectively.

A dynamic production function, expressed as shown in Eq. (2), is produced by taking the logarithms of Eq. (1):

$$
\mathrm{Y}_{\mathrm{i}, \mathrm{t}}=\tau+\gamma_{1} L_{\mathrm{i}, \mathrm{t}}+\gamma_{2} K_{D i, t}+\gamma_{3} K_{F i, t}+\varepsilon_{\mathrm{i}, \mathrm{t}}
$$

Equation (2) is expanded by including other factors that explain economic growth, denoted by $F^{3}$ and interaction term between the labour force and FDI, $L^{*} K_{F}$. The addition of the interaction terms follows Elboiashi $(2011)^{4}$ and Kitonyo (2018)

$$
\begin{aligned}
& \mathrm{Y}_{\mathrm{i}, \mathrm{t}}=\tau+\gamma_{1} L_{\mathrm{i}, \mathrm{t}}+\gamma_{2} K_{D i, t}+\gamma_{3} K_{F i, t}+\gamma_{4} W_{i, t}+\gamma_{5} \\
& \left(L * K_{F}\right)_{\mathrm{i}, \mathrm{t}}+\mathrm{e}_{\mathrm{t}}+\mathrm{v}_{\mathrm{i}}+\varepsilon_{\mathrm{i}, \mathrm{t}}
\end{aligned}
$$

where,

Y

$L$

$K_{D}$

$K_{F}$

$W$

$\left(L^{*} K_{F}\right)$

$\tau$

$e_{t}$

$v_{\mathrm{i}}$

$\varepsilon_{i, t} \quad:$ A normally distributed error term

$\gamma_{1}, \gamma_{2}, \gamma_{3}, \gamma_{4}$ and $\gamma_{5}$ : The parameters to be estimated

The incorporation of dynamics into Eq. (3) requires that the equation be rewritten as an AR (1) ${ }^{6}$ model by including the past values of GDP/capita as an independent variable. This operation produces Eq. (4): 
$\mathrm{Y}_{\mathrm{i}, \mathrm{t}}=\tau+\gamma_{0} \mathrm{Y}_{\mathrm{i}, \mathrm{t}-1}+\gamma_{1} L_{\mathrm{i}, \mathrm{t}}+\gamma_{2} K_{D i, t}+\gamma_{3} K_{F i, t}+\gamma_{4} W_{i, t}+$

$\gamma_{5}\left(L * K_{F}\right)_{\mathrm{i}, \mathrm{t}}+\mathrm{e}_{\mathrm{t}}+\mathrm{v}_{\mathrm{i}}+\varepsilon_{\mathrm{i}, \mathrm{t}}$

where,

$\gamma_{0}$ : The parameter for the difference of lagged values of GDP/capita

The rest of the terms are as explained in Eq. (3).

Econometric model: The estimated equation used is given by Eq. (5):

$$
\begin{aligned}
& \mathrm{GDPPC}_{\mathrm{i}, \mathrm{t}}=\tau+\gamma_{0} \mathrm{GDPPC}_{\mathrm{i}, 0}+\gamma_{1} \mathrm{GDPPC}_{\mathrm{i}, \mathrm{t}-1}+ \\
& \gamma_{2} \mathrm{HUMCAP}_{\mathrm{i}, \mathrm{t}}+\gamma_{3} \mathrm{DINV}_{\mathrm{i}, \mathrm{t}}+\gamma_{4} \mathrm{TRADE}_{\mathrm{i}, \mathrm{t}}+ \\
& \gamma_{5} \mathrm{PUBDEBT}_{\mathrm{i}, \mathrm{t}}+\gamma_{6} \mathrm{INFLA}_{\mathrm{i}, \mathrm{t}}+\gamma_{7} \mathrm{FDI}_{\mathrm{i}, \mathrm{t}}+\gamma_{8} \\
& \left(\mathrm{HUMCAP}^{\mathrm{H} D I}\right)_{\mathrm{i}, \mathrm{t}}+\mathrm{e}_{\mathrm{t}}+\mathrm{v}_{\mathrm{i}}+\mathrm{u}_{\mathrm{it}}
\end{aligned}
$$

where,

$\mathrm{GDPPC}_{\mathrm{i}, \mathrm{t}}$

$\mathrm{GDPPC}_{\mathrm{i}, \mathrm{t}-1}$

HUMCAP

DINV

TRADE

PUBDEBT

INFLA

FDI

HUMCAP*FDI

$\gamma_{0}$

$\tau$

$\mathrm{e}_{\mathrm{t}}$

$v_{\mathrm{i}}$
: The GDP/capita in country $i$ during period $t$

: Lagged GDP/capita

: The human capital stock (measured by the Human Development Index, HDI)

: The domestic investment (measured by the share of gross fixed capital formation in constant dollars to GDP ratio)

: Trade openness (measured by the share of total imports and exports to GDP)

: The public debt (measured by the share of the gross debt liabilities to GDP ratio)

: The changes in annual general level of prices

: The foreign direct investment

: The interaction term between the human capital development and FDI

: A parameter reflecting the speed of convergence of GDP/capita from one period to the next

: A constant

: Time-specific effects which are also assumed to be independently and identically distributed over all time periods

: An unobserved countryspecific effects which are independently and identically distributed over $\mathrm{u}_{\mathrm{it}}$

the countries in COMESA region

: The error term which is assumed to be independently and identically distributed over all time periods in country $i$

$\gamma_{1}, \gamma_{2}, \gamma_{3}, \gamma_{4}, \gamma_{5}, \gamma_{6}, \gamma_{7}, \gamma_{8}:$ The estimable parameters

A positive (negative) sign of the parameters suggests that an increase in the respective variable by one percent leads to an increase (decrease) of GDP/capita by the percentage size of the parameter. In model Eq. (5), the coefficient $\gamma_{7}$ is interpreted as the marginal rise in the impact of FDI on the real GDP/capita when the development of human capital improves. The converse also holds true.

Variables used in the study: The growth performance of GDPPC measures the overall performance of an economy. The GDP/capita in this study is measured by the nominal real GDP/capita deflated by the GDP deflator (base $2000=100$ ). The lower the starting level of real GDP/capita the higher the predicted growth rate (Barro, 1991; Kitonyo, 2018; Levine and Renelt, 1992). Growth is expected to be rapid at first then slows down as the economy becomes more developed. Consequently, $\gamma_{0}<0$.

Additionally, the current GDPPC is expected to be affected positively by lagged GDP/capita, GDPPC $\mathrm{C}_{\mathrm{i}, \mathrm{t}-1 \text {, }}$. In other words, high values of real GDP per capita in the past are expected to positively influence growth of the current real GDP/capita in the COMESA region. Hence, $\gamma_{1}>0$.

HUMCAP, represented by the Human Development Index (HDI) in this study, is expected to affect current GDPPC positively and enhance the ability of the COMESA region to absorb and benefit from spillovers of FDI. According to Jongwanich (2007), Kitonyo et al. (2017a, 2017b) and Kitonyo (2018) high level of human development in terms of leading a long and healthy life, being knowledgeable and educated and having a decent standard of living promotes economic growth and enable the host economy to absorb and benefit from spillovers of FDI. It is expected that $\gamma_{2}>0$.

DINV has a positive effect on the GDPPC (Kitonyo et al. 2017a, 2017b). Increased rate of domestic capital investment promote productivity in an economy. Domestic investment in this study is represented by the share of gross fixed capital formation in constant dollars to GDP ratio. Thus, $\gamma_{3}>0$.

Measured by the share of trade (imports and exports) to GDP, trade openness of the host economy is expected to enlarge markets and expand domestic investment so as to meet increased demand for goods and services (Feder, 1982). The performance of 
COMESA region's total imports and exports and adoption of trade liberalization by member countries could also increase the significance of the impact of short term foreign capital flows on economic growth. TRADE is therefore expected to have a positive impact on the GDPPC as well as enhance the ability of the COMESA region to absorb and benefit from the spillovers of FDI. Hence, it is expected that $\gamma_{4}>0$.

High level of debt liabilities in the form of Special Drawing Rights, currency and deposits, debt securities, loans, insurance, pensions and standardized guarantee schemes and other accounts payable, represents the risk for an economy to encounter difficulties in reimbursing its public debt and to face a financial crisis. The presence of a large public debt can also adversely affect investment by reducing the funds available to invest, given that the return from new investments will be overly taxed in order for the government to repay the debt. The study anticipates a negative impact of PUBDEBT, measured by the share of the gross debt liabilities to GDP ratio, on GDPPC. Therefore, $\gamma_{5}<0$.

Macroeconomic instability, reflected by high, rising and unstable general levels of prices, reduces real future profits and cause uncertainties to investors. According to Lorain and Vergara (1993) and Servén and Solimano (1992), macroeconomic instability provides uncertain and unreliable economic environment, which does not allow the investors to benefit from the existing profit opportunities. The priori expectation is that INFLA, measured by the annual percentage change in the Consumer Price Index (CPI), has a negative impact on the GDPPC of the host country. Therefore, $\gamma_{6}<0$.

FDI, measured by net FDI stocks ${ }^{7}$, promotes GDP per capita growth of host countries by filling the gap between desired investment and domestically mobilized savings, complementing domestic investment, creating employment, increasing tax revenues, introducing new technology, improving managerial and labour skills
(Kitonyo, 2018). Hence, it is expected to impact positively on current GDP growth. Hence, $\gamma_{7}>0$.

Analysis of data and technique of estimation: The study utilizes a panel data drawn from 19 countries in the COMESA region over 2000-2015 period. A dynamic panel data GDP/capita model, where the lagged dependent variable, the GDP/capita, is added to the explanatory variables, is estimated. It is argued that the lagged GDP/capita has a positive impact on the current GDP/capita.

This study uses the Generalized Method of Moments (GMM) technique suggested by Arellano and Bond (1991) to account for dynamics and resolves endogeneity, unobserved heterogeneity and short panel bias problems.

\section{RESULTS AND DISCUSSION}

The analysis begins by providing the summary descriptive statistics in Table 1 that describe the features of the data used in the study.

The results of the correlation of variables are presented in Table 2. An explanatory variables correlation matrix is used to test the presence of multicollinearity in the dynamic panel data GDP/capita model specified in Eq. (5).

The results in Table 2 indicates that all the zeroorder correlation coefficients between any two regressors are low, ruling out the presence of perfect or near perfect linear relationship. Thus, there is no relationship among the independent variables, implying that the regression obtains determinate coefficient and fiite standard errors.

On one hand, Table 2 indicates that GDP/capita has a positive correlation with domestic investment and human capital development as theoretically predicted.

Table 1: Summary statistics

\begin{tabular}{llllll}
\hline Variable & Mean & Median & Min. & Max. & S.D. \\
\hline GDP/capita (PPP US dollars) & $4,911.76$ & $1,835.72$ & 377.20 & $29,646.60$ & $6,541.35$ \\
Domestic investment (\% GDP) & 21.15 & 19.85 & 2.00 & 51.79 & 8.84 \\
Human capital development (HDI) & 0.46 & 0.42 & 0.22 & 0.81 & 0.15 \\
Public debt (\% GDP) & 65.12 & 52.67 & 1.01 & 202.05 & 46.17 \\
Openness of the economy (\% GDP) & 76.07 & 65.50 & 21.00 & 225.00 & 43.04 \\
Inflation (\%) & 11.41 & 7.94 & 0.06 & 94.96 & 12.43 \\
Foreign direct investment (\% GDP) & 28.43 & 20.65 & 0.00 & 168.66 & 29.13 \\
\hline Min
\end{tabular}

Min.: Minimum; Max.: Maximum; S.D.: Standard deviation; Authors' computations

Table 2: Correlation matrix of variables in levels

\begin{tabular}{|c|c|c|c|c|c|c|c|c|}
\hline Variable & $\mathrm{GDPPC}_{\mathrm{I}, \mathrm{t}}$ & $\mathrm{GDPCC}_{\mathrm{I}, 0}$ & DINV & HUMCAP & PUBDEBT & TRADE & INFLA & FDI \\
\hline$\overline{\text { GDPCC }}_{\mathrm{i}, \mathrm{t}}$ & 1.000 & & & & & & & \\
\hline $\mathrm{GDPPC}_{\mathrm{i}, 0}$ & -0.007 & 1.000 & & & & & & \\
\hline DINV & 0.338 & 0.325 & 1.000 & & & & & \\
\hline HUMCAP & 0.585 & 0.089 & 0.273 & 1.000 & & & & \\
\hline PUBDEBT & -0.124 & -0.112 & -0.220 & -0.182 & 1.000 & & & \\
\hline TRADE & -0.570 & 0.578 & 0.119 & 0.590 & -0.097 & 1.000 & & \\
\hline INFLA & -0.166 & -0.219 & -0.059 & -0.123 & 0.208 & -0.040 & 1.000 & \\
\hline FDI & 0.018 & 0.367 & 0.220 & 0.363 & 0.061 & 0.598 & -0.063 & 1.000 \\
\hline
\end{tabular}

Author's own computations 
Table 3: Arellano and Bond (1991) GMM-difference estimates of the impact of FDI on economic growth in the COMESA region, 2000-2015

\begin{tabular}{|c|c|}
\hline$\underline{\text { Dependent variable }=\text { GDP/capita }(\text { GDPPC) }}$ & $\begin{array}{l}\text { Dynamic panel data } \\
\text { GDP/capita model }\end{array}$ \\
\hline Initial GDP/capita $\left(\mathrm{GDPPC}_{\mathrm{i}, 0}\right)$ & $-0.263(0.031)^{* *}$ \\
\hline GDP/capita $\left(\mathrm{GDPPC}_{\mathrm{t}-1}\right)$ & $0.148(0.014)^{* *}$ \\
\hline Human capital development (HUMCAP) & $0.605(0.024)^{* *}$ \\
\hline Domestic investment (DINV) & $0.152(0.036)^{* *}$ \\
\hline Public debt (PUBDEBT) & $-0.145(0.027)^{* *}$ \\
\hline Trade openness (TRADE) & $-0.072(0.651)$ \\
\hline Inflation (INFLA) & $-0.143(0.013) * *$ \\
\hline Foreign direct investment (FDI) & $-0.352(0.027)^{* *}$ \\
\hline FDI*HUMCAP & $0.758(0.013)^{* * *}$ \\
\hline Constant & $0.272(0.281)$ \\
\hline Number of observations & 228.000 \\
\hline Number of instruments & 119.000 \\
\hline A-B test $1^{\text {st }}$ order & $-2.230(0.026)^{* *}$ \\
\hline A-B test $2^{\text {nd }}$ order & $-0.788(0.431)$ \\
\hline Sargan over-identification test & $163.590(0.100)$ \\
\hline Wald (joint) test & $2311.910(0.000)^{* * *}$ \\
\hline Adjustment speed, $\lambda=1-\gamma_{0}$ & 0.852 \\
\hline \multicolumn{2}{|c|}{$\begin{array}{l}\text { p-values are reported in parentheses with }{ }^{*}, * *, * * * \text { denoting } \\
\text { significance at } 10,5 \text { and } 1 \% \text {, respectively; The Arellano and Bond } \\
\text { (A-B) Z-statistic tests the null hypothesis that the residuals are first- } \\
\text { order correlated (A-B test } 1^{\text {st }} \text { order) and the residuals are not second- } \\
\text { order correlated (A-B test } 2^{\text {nd }} \text { order); The Wald test, a test of joint } \\
\text { significance, tests the null hypothesis that the coefficients of time } \\
\text { dummies are zero; Authors' computations }\end{array}$} \\
\hline
\end{tabular}

The FDI is positively related to GDP/capita in line with economic theory.

On the other hand, the Table shows that growth is negatively correlated with initial GDP/capita, public debt and inflation, as theoretically predicted. However, economic growth is negatively correlated to openness of the economy, contrary to economic theory.

Finally, Table 3 presents estimates of the dynamic panel GDP/capita Eq. (5). The first column describes the estimated variables, number of observations, number of instruments, diagnostic tests and adjustment speed. The second column presents the estimates generated by using the one-step Arellano and Bond (1991) GMM difference estimator.

The diagnostic test results in terms of lack of second-order serial correlation, validity of instruments variables and statistically significant Wald tests shows that the model is correctly specified and GMMdifference estimator yields reliable and efficient results.

The regression results suggest that FDI matter for economic growth in the COMESA region. The negative and significant coefficient of the impact of FDI on the GDP/capita imply that a rise in FDI leads to a direct decrease in the growth of GDP/capita in the COMESA region. This finding is supported by previous authors such as Agbloyor et al. (2014), Bos et al. (1974), Jugrnath et al. (2016), Kitonyo (2018), Prebisch (1968), Saltz (1992), Saqib et al. (2013) and Singer (1950) and among others, who found a negative and statistically significant effect of FDI on growth. The results are however contrary to the general belief that FDI is a key source of growth (Borensztein et al., 1998; Findlay,
1978; Hayami, 2001; Jenkins and Thomas, 2002; Todaro and Smith, 2003; World Bank, 2000). The statistically significant coefficient of the FDI implies that the investment has a significant positive impact on the GDP/capita in the COMESA region.

The negative impact of FDI on the growth of GDP/capita in Africa could be explained by a number of reasons, including to the lack of synergies between FDI and domestic investment (Ndikumana and Verick, 2008); few linkages to domestic firms, spillover opportunities and little value-added processing of the resources (Morrissey, 2012); lack of competition among the FDI players in Africa and distorted regulatory and incentive frameworks (United Nations Conference on Trade and Development, 2016); and poor governance, weak institutions, relatively high corruption and political instability (Asiedu, 2006), among others.

The results shows that development of human capital has a positive and significant impact on economic growth at 5\% level of significance, concurring with Jongwanich (2007), Kitonyo et al. (2017a, 2017b) and Kitonyo (2018). Further, the interaction term $\left(\right.$ FDI*HUMCAP) ${ }^{8}$ has a positive and significant coefficient at $1 \%$ level of significance, implying that development of human capital has a positive effect on the growth impact of FDI in the COMESA region. The result confirms findings by previous studies by Ndoricimpa (2009), Borensztein et al. (1998) and Saggi (2002), among others. This result means that development in the human capital has a positive effect on the growth impact of FDI in the COMESA region.

The coefficient of the initial GDP/capita is statistically significant at 5\% level of significance, supporting conditional convergence. Additionally, the parameter of the past values of GDP/capita is statistically significant at $5 \%$ level of significance, suggesting that the past values of GDP/capita growth has a significant positive impact on the current economic growth rate.

Consistent with Cohen (1993), Kitonyo et al. (2017a, 2017b) and Lorain and Vergara (1993) public debt and inflation exerts a negative and statistically significant impact on the GDP/capita in the COMESA region.

\section{CONCLUSION}

The objective of this study is to investigate the growth impact of FDI in the Common Market for Eastern and Southern Africa region over the period 2000-2015. The empirical studies reviewed in this study showed conflicting outcomes, where results of some studies are positive, while others are negative and indeterminate. In order to attain the aim of the study, a dynamic panel data GDP/capita model is estimated 
using the one-step GMM estimators suggested by Arellano and Bond (1991).

The study confirms conditional convergence and finds that FDI exerts a negative and statistically significant impact on GDP/capita in the region. It also finds that the past values of GDP/capita and domestic investment affects growth positively. Additionally, development in human capital is found to exert a positive impact on the GDP/capita and enhance the ability of the region to absorb and benefit from FDI. Lastly, high inflation, growth in public debt exhibit a negative impact on the GDP per capita in the COMESA region.

The governments of the states of the COMESA region are recommended to target to attract beneficial FDI that significantly increase employment, enhance skills and boost the competitiveness of local enterprises and therefore promote growth. They should also improve human capital development so as to exploit the positive impact of FDI. They could consider allocating more resources to support initiatives that ensure people lead a long and healthy life, are knowledgeable and enjoy a decent standard of living.

\section{ACKNOWLEDGMENT}

The author wishes to express his heart felt appreciation to Professor Tabitha Kiriti-Ng'ang'a and Dr. Daniel Okado Abala of the School of Economics, University of Nairobi, for their guidance and useful comments in writing this study.

\section{CONFLICT OF INTEREST}

We do not have any conflict of interest to declare.

\section{REFERENCES}

Adams, S., 2009. Foreign direct investment, domestic investment, and economic growth in sub-Saharan Africa. J. Pol. Model., 31(6): 939-949.

Agbloyor, E.K., J.Y. Abor, C.K.D. Adjasi and A. Yawson, 2014. Private capital flows and economic growth in Africa: The role of domestic financial markets. J. Int. Financ. Mark. I., 30: 137-152.

Agbloyor, E.K., A. Gyeke-Dako, R. Kuipo and J.Y. Abor, 2016. Foreign direct investment and economic growth in SSA: The role of institutions. Thunderbird Int. Bus. Rev., 58(5): 479-497.

Ajayi, S.I., 2005. Globalization and Africa: The Myth and Reality. In: Nathalia, D. and L. Square (Eds.), Globalization and Equity: Perspectives from the Developing World. Northampton, Massachusetts, Edward Edgar.
Ajayi, S.I., 2007. The Determinants of Foreign Direct Investment: A Survey of the Evidence. In: Ajayi S.I. (Ed.), Foreign Direct Investment in subSaharan Africa: Determinants, Origins, Targets, Impact and Potential, African Economic Research Consortium, Nairobi, pp: 11-32.

Arellano, M. and S. Bond, 1991. Some tests of specification for panel data: Monte carlo evidence and an application to employment equations. Rev. Econ. Stud., 58: 277-297.

Asiedu, E., 2006. Foreign direct investment in Africa: The role of natural resources, market size, government policy, institutions and political instability. World Econ., 29(1): 63-77.

Balasubramanyam, V.N., M. Salisu and D. Sapsford, 1996. Foreign Direct Investment and growth in EP and IS countries. Econ. J., 106(434): 92-105.

Barro, R.J., 1991. Economic growth in a cross section of countries. Q. J. Econ., 106: 407-443.

Blomström, M. and A. Kokko, 1998. Multinational corporations and spillovers. J. Econ. Surv., 12(3): 247-277.

Borensztein, E., J. de Gregorio and J.W. Lee, 1998. How does foreign direct investment affect economic growth? J. Foreign Econ., 45: 115-135.

Bos, H., M. Sanders and C. Secchi, 1974. Private Foreign Investment in Developing Countries: A Quantitative Study on Macro-economic Effects. Riedel Publishing, Dordrecht.

Campos, N.F. and Y. Kinoshita, 2003. Why Does FDI go Where it Goes? New Evidence from the Transition Economies. International Monetary Fund Institute IMF Working Paper, Washington, D.C.

Carkovic, M. and R. Levine, 2002. Does Foreign Direct Investment Accelerate Economic Growth? University of Minnesota Working Paper, University of Minnesota, Minneapolis.

Chen, E.K.Y., 1990. Foreign Direct Investment in Asia. Asian Productivity Organization, Tokyo.

Cohen, D., 1993. Low investment and large LDC debt in the 1980's. Am. Econ. Rev., 83(3): 437-449.

De Mello, L.R., 1997. Foreign direct investment in developing countries and growth: A selective survey. J. Dev. Stud., 34(1): 1-34.

De Mello, L.R., 1999. Foreign direct investment-led growth: Evidence from time series and panel data. Oxford Econ. Papers, 51: 133-151.

Elboiashi, H.A., 2011. The effect of FDI and other foreign capital inflows on growth and investment in developing economies. Unpublished Ph.D. Thesis, University of Glasgow, Glasgow.

Feder, G., 1982. On exports and economic growth. J. Dev. Econ., 12(1-2): 59-73.

Findlay, R., 1978. Relative backwardness, direct foreign investment, and the transfer of technology: A simple dynamic model. Q. J. Econ., 92(1): 1-16. 
Firebaugh, G., 1992. Growth effects of foreign and domestic investment. Am. J. Sociol., 98(1): 105-130.

Hayami, Y., 2001. Development Economics: From the Poverty to the Wealth of Nations. Oxford University Press, New York.

Herzer, D., S. Klasen and F.N. Lehmann, 2008. In search of FDI-led growth in developing countries: The way forward. Econ. Modell., 25(5): 793-810.

International Monetary Fund, 2016. World Economic Outlook. International Monetary Fund, Washington, D.C.

Jenkins, C. and L. Thomas, 2002. Foreign direct investment in southern Africa: Determinants, characteristics and implications for economic growth and poverty alleviation. Final Report, October, Globalization and Poverty Project, Centre for the Study of African Economies, University of Oxford.

Jongwanich, J., 2007. Worker's Remittances, Economic Growth and Poverty in Developing Asia and the Pacific Countries. UNESCAP Working Paper WP/07/01, United Nations Economic and Social Commission for Asia and the Pacific, United Nations, New York, NY.

Jugrnath, B., N. Chukun and S. Fauzel, 2016. Foreign direct investment \& economic growth in SubSaharan Africa: An empirical study. Theor. Econ. Lett., 6(4): 798-807.

Katerina, L., P. John and V. Athanasios, 2004. Foreign direct investment and economic growth in transition economies. South-Eastern Eur. J. Econ., 2(1): 97-110.

Kim, D.D.K. and J.S. Seo, 2003. Does FDI inflow crowd out domestic investment in Korea? J. Econ. Stud., 30(6): 605-622.

Kitonyo, P., Kiriti-Ng'anga and D.O. Abala, 2017a. Remittances-growth nexus: What does the evidence in the common market for eastern and Southern Africa region show? Curr. Res. J. Econ. Res., 9(1): 13-24.

Kitonyo, P., Kiriti-Ng'anga and D.O. Abala, 2017 b. Modelling the impact of short term foreign capital flows on economic growth in the common market for eastern and southern Africa Region: A dynamic panel data analysis. Curr. Res. J. Econ. Res., 9(1): $1-12$.

Kitonyo, P., 2018. The impact of foreign capital on economic growth in the common market for eastern and southern Africa region. Unpublished Ph.D. Thesis, University of Nairobi, Nairobi.

Levine, R. and D. Renelt, 1992. A sensitivity analysis of cross-country growth regressions. Am. Econ Rev., 82(4): 942-963.

Li, X. and X. Liu, 2005. Foreign direct investment and economic growth: An increasingly endogenous relationship. World Dev., 33(3): 393-407.
Lorain, F. and R. Vergara, 1993. Investment and Macroeconomic Adjustment: The Case of East Asia. In: Servén, L. and A. Solimano (Eds.), Striving for Growth after Adjustment. Washington, D.C.

Morrissey, O., 2012. FDI in sub-Saharan Africa: Few linkages, fewer Spillovers. Eur. J. Dev. Res., 24: 26-31.

Mutenyo, J., 2008. Does foreign direct investment stimulate economic growth in sub-sahara Africa? Proceeding of the ESRC Development Economics Conference, University of Sussex, London, UK.

Mwega, F.M. and R.W. Ngugi, 2007. Foreign Direct Investment in Kenya. In: Ajayi, S.I. (Ed.), Foreign Direct Investment in sub-Saharan Africa: Origins, Targets, Impact and Potential. Africa Economic Research Consortium, Nairobi, pp: 119-143.

Mwilima, N., 2003. Foreign Direct Investment Social Observatory Pilot Project. Labour Resource and Research Institute (LaRRI), Windhoek.

Ndikumana, L. and S. Verick, 2008. The Linkages between FDI and Domestic Investment: Unravelling the Developmental Impact of Foreign Direct Investment in sub-Saharan Africa. IZA Discussion Papers No. 3296, Institute for the Study of Labour, Bonn.

Ndoricimpa, A., 2009. Foreign direct investment, exports and economic growth in COMESA countries: A heterogeneous panel causality approach. Unpublished M.A. Thesis, Makerere University, Kampala.

Prebisch, R., 1968. Development Problems of the Peripheral Countries and the Terms of TOPEN. In: Theberge, J.D. (Ed.), Economics of Trade and Development. John Wiley and Sons Incorporation, New York.

Saggi, K., 2002. On technology transfer from Topen and foreign direct investment. World Bank Res. Observ., 17: 191-236.

Saltz, S., 1992. The negative correlation between foreign direct investment and economic growth in the third world: Theory and evidence. Riv. Int. Sci. Econ. Com., 39: 617-633.

Seetanah, B. and A.J. Khadaroo, 2006. Foreign direct investment and growth: New evidences from subSaharan African countries. Proceeding of the Study of African Economies Conference on Economic Development in Africa, Oxford, 20 March.

Servén, L. and A. Solimano, 1992. Private investment and macroeconomic adjustment: A survey. World Bank Res. Observ., 7(1): 95-114.

Singer, H.W., 1950. U.S. foreign investment in underdeveloped areas: The distribution of gains between investing and borrowing countries. Am. Econ. Rev., 40(02): 473-485.

Todaro, M.P. and S.C. Smith, 2003. Economic Development. Pearson Education Ltd., Harlow. 
Curr. Res. J. Econ. Theory, 10(1): 1-10, 2018

Ugochukwu, U., O. Okore and J.O. Onoh, 2013. The impact of foreign direct investment on the Nigerian economy. Eur. J. Bus. Manage., 5(2): 25-33.

United Nations Conference on Trade and Development, 2016. Trade and development report. United Nations Conference on Trade and Development, Geneva.

Van den Berg, H., 2001. Economic Growth and Development. McGraw-Hill, Singapore.

World Bank, 1996. World Debt Tables: External Finance for Developing Countries 1 (Analysis and Summary Tables). World Bank, Washington, D.C.

World Bank, 2000. World Business Environment Survey. World Bank, Washington, D.C.

$\mathrm{Xu}$, B., 2000. Multinational enterprises, technology diffusion, and host country productivity growth. J. Dev. Econ., 62(2): 477-493.

\section{End notes:}

1: Mergers and related non-equity forms of FDI such as international joint ventures are reported together. Joint ventures are businesses arrangements in which two or more parties agree to pool their resources for the purpose of accomplishing a specific task. This task can either be a new project or any other business activity. The parties retain their distinct identities in the course of the business arrangement.
2: These countries include Djibouti (2.4\%/annum), Egypt (2.4\%/annum), Ethiopia (6.0\%/annum), Libya (2.3\%), Mauritius (3.5\%/annum), Rwanda (4.7\%/annum), Seychelles (2.4\%/annum), Sudan (4.1\%/annum), Uganda (3.1\%/annum) and Zambia (3.6\%/annum), among others (International Monetary Fund, 2016).

3 : The other factors that influence economic growth include among others openness of the economy, public debt and inflation.

4. Elboiashi (2011) interacted the human capital, technology gap, infrastructure development, institution quality, financial market development and trade openness with FDI so as to investigate the effect of the host country conditions on the impact of FDI in 76 developing countries between 1980 and 2005 .

5 : Kitonyo (2018) investigated the growth impact of aggregated and disaggregated foreign capital and financial resources in the Common Market for Eastern and Southern Africa (COMESA). The author tested the hypothesis that absorptive capacity affect the impact of the aggregated and disaggregated foreign capital and financial resources on economic growth by interacting their respective variables with different factors of absorptive capacity. The study tested the significance of the interacted coefficient.

${ }^{6}$ : AR (1) stands for autoregressive dynamic panel data model of order one.

7 : $\quad$ FDI stock is the value of the share of their capital and reserves (including retained profits) attributable to the parent enterprise, plus the net indebtedness of affiliates to the parent enterprises (United Nations Conference on Trade and Development, 2016).

${ }^{8}$ : The interaction term (FDI*HUMCAP) capture the effect of a well-developed human capital is likely to have on the absorptive capability of the stock of foreign direct investment including technology and knowledge. 